Maria Kalinowska*

\title{
Historia i ironia. \\ Wspomnienie o Profesor Marii Żmigrodzkiej
}

DOI: http://dx.doi.org/10.12775/LC.2017.042

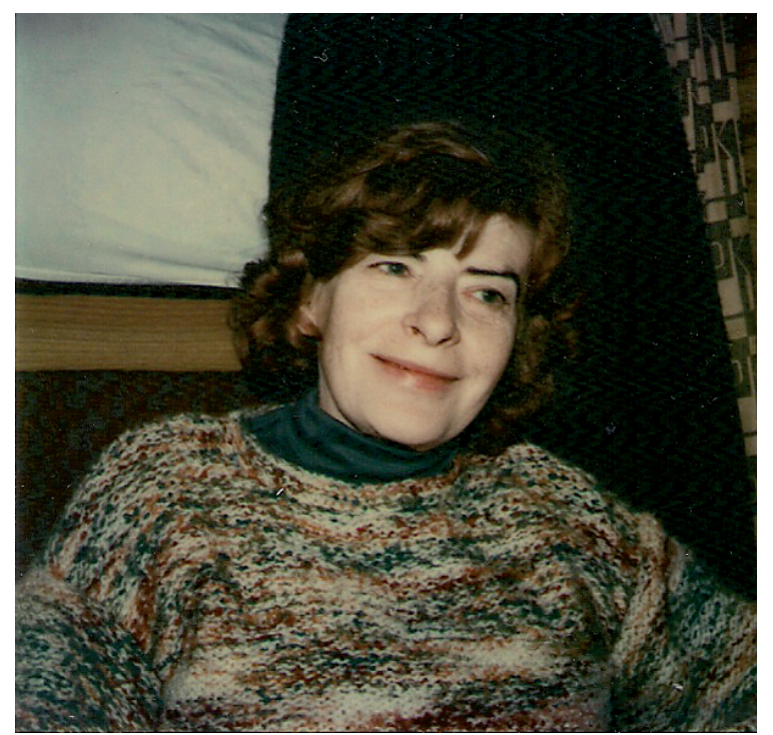

Profesor Maria Żmigrodzka

Fot. ze zbiorów prywatnego Archiwum Prof. M. Żmigrodzkiej

hyba każdego z nas, humanistów piszących o literaturze i sztuce, musiały zastanowić i może dotknąć słowa Mickiewiczowskiego Konrada, który w swojej buntowni-

\footnotetext{
* Profesor zwyczajny na Wydziale Artes Liberales Uniwersytetu Warszawskiego. Do roku 2014 profesor w Instytucie Literatury Polskiej Uniwersytetu Mikołaja Kopernika w Toruniu. Autorka książek o literaturze romantycznej oraz o polskiej recepcji kultury greckiej. Kierownik ogólnopolskich projektów badań nad filhellenizmem oraz recepcją Sparty w kulturze polskiej.E-mail: mariakalinowska@al.uw.edu.pl.
} 
czej Improwizacji wyrażając zwątpienie w trwałość nauki, mówi: „nauka prędko gnije”. Równocześnie każdy z nas badających dzieła artystyczne o długim, przekraczającym współczesność, trwaniu, musi jednak pogodzić się z faktem nietrwałości tej dziedziny naszej aktywności. Czy jesteśmy „„ługami wielkości”, czy chłodnymi strukturalistami, mamy świadomość, że nasze literaturoznawcze prace bardzo szybko starzeją się, że pojawiają się nowe spojrzenia, nowe metody i punkty widzenia, wreszcie nowe mody, które dezaktualizują czy może odsuwają od głównego nurtu dawne prace, kiedyś nawet mające znaczenie fundamentalne. Badacze literatury ratują się przed ową nietrwałością nauki na różne sposoby: zbliżając się ku pisarstwu bardziej literackiemu, emocjonalnemu i subiektywnemu, często eseistycznemu, zbliżając się do publicystyki zanurzonej w aktualnej problematyce społecznej, niekiedy przeciwnie - uciekając od wszelkiej niepewności ku formułowaniu tez możliwie zobiektywizowanych i weryfikowalnych, zatem ku modelowi nauk ścisłych.

Do powyższych refleksji, dość przecież oczywistych dla każdego literaturoznawcy, skłoniła mnie kolejna, czy raczej wciąż ponawiana, lektura prac Profesor Marii Żmigrodzkiej, wybitnej znawczyni literatury romantycznej i szerzej - kultury dziewiętnastowiecznej. Fenomen dorobku naukowego Marii Żmigrodzkiej zaprzecza tym - pozornie tylko, jak widać, oczywistym tezom. Rozprawy Uczonej, pisane przed pięćdziesięcioma, czterdziestu czy trzydziestu laty nie zdezaktualizowały się; uważane dziś za klasyczne, są nadal nowoczesne i nadal nie tylko określają standardy naukowości, ale stanowią żywe wyzwanie dla kolejnych już roczników badaczy polskiej literatury dziewiętnastowiecznej. Najbardziej wyrazistym przykładem tych mistrzowskich studiów są przekrojowe prace dotyczące podstawowych zagadnień światopoglądowych romantyzmu, zwłaszcza romantycznej historiozofii, oraz kategorii estetycznych, np. ironii, powiązanych z opisem struktur literackich, zwłaszcza gatunków epickich czy form narracyjnych. Część tych fundamentalnych prac publikowała Maria Żmigrodzka w redagowanej ${ }^{1}$ przez siebie serii Problemów polskiego romantyzmu, notabene wyznaczających do dziś, czyli już przez ponad czterdzieści lat, horyzont polskich badań literaturoznawczych nad tą epoką. Jednak nie tylko przekrojowe studia nad romantyzmem są przykładem fenomenu szczególnej aktualności pisarstwa naukowego Marii Żmigrodzkiej. Jedna z fundamentalnych rozpraw Uczonej, obszerna monografia pt. Orzeszkowa. Młodość pozytywizmu², napisana w roku 1965, czytana dziś okazuje się dużo bardziej nowatorska w odsłanianiu kondycji kobiety jako problemu kulturowego i społecznego niż epatujące - często zresztą pozorną - bezkompromisowością tezy współczesnych, dwudziestopierwszowiecznych feministek.

Jaka jest tajemnica prac Marii Żmigrodzkiej? Na czym polega ich fenomen? Jakimi właściwościami odznacza się warsztat literaturoznawcy wypracowany przez Profesor Marię Żmigrodzką, o której Jej uczeń, Marek Kwapiszewski, napisał, że reprezentowała „najwyższej miary format intelektualno-duchowy"3?

Maria Żmigrodzka urodziła się w roku 1922, należała więc do pokolenia szczególnie przez historię doświadczonego. Elżbieta Kiślak, również uczennica Profesor Żmigrodzkiej, tak charakteryzowała młodość Uczonej:

\footnotetext{
1 Bądź współredagowanej, jak seria I przygotowana wspólnie z Zofią Lewinówną: Wrocław 1971. Seria II, Wrocław 1974. Seria III, Wrocław 1981.

2 M. Żmigrodzka, Orzeszkowa. Młodość pozytywizmu, Warszawa 1965.

3 M. Kwapiszewski, Opus magnum, „Annales Universitatis Mariae Curie-Skłodowska. Sectio FF, Philologiae” 2004, t. XXII (tu obszerna prezentacja twórczości naukowej uczonej), s. 16.
} 
Poczucie obywatelskiego obowiązku, które kazało licealistce w pierwszych tygodniach wojennych zgłosić się na ochotnika do pracy w szpitalu, wśród rannych żołnierzy, ugruntowała [...] tradycja rodzinna, legionowa, a zarazem socjalistyczna, stroniąca od bogoojczyźnianych frazesów, wolnomyślicielska - ojciec był oficerem II Brygady. W Warszawie zamieszkała już po jego śmierci, na kilka lat przed wojną, dzieciństwo spędziła zaś w prowincjonalnych garnizonach i lubiła podkreślać swoją nabytą kresowość. Po maturze zdanej na tajnych kompletach w 1940 roku rozpoczęła studia na podziemnych uniwersytetach [... ]. Naukę łączyła z akowską konspiracją, ale ostatecznie w walkach powstańczych bezpośredniego udziału nie wzięła, ponieważ jej kobiecy oddział minerski Kedywu odkomenderowano od razu do zaminowywania mostów pod Warszawę̨4.

Po wojnie zamieszkała w Łodzi i tu podjęła studia polonistyczne. Prof. Maria Janion tak wspomina ten okres: „Wtedy, na pierwszym roku, poznałam panią Marynę - Marię Żmigrodzką”, dodając równocześnie: „Zobaczyłam »prześliczną rudowłosą «, jak z wiersza Apollinaire’a. A ta rudowłosa była najinteligentniejsza i najlepiej wykształcona z nas wszystkich. Olśniewająca postać”s.

Wszystko jej przychodziło łatwo, nawet czytanie tych stosów Orzeszkowej i Wyspiańskiego. Czasami mi nawet to i owo streszczała, kiedy już nie byłam w stanie przyswajać. Miała w ogóle lepsze oceny; ja byłam bardziej dziwaczką, ona urodzoną prymuską. Bez żadnego wysiłku, skromnie, z dobrotliwą ironią zaginała każdego.

Rude loki bardzo zwracały uwagę w czasie okupacji, były jakieś zaczepki ze strony szmalcowników, że może to ruda Żydówka. Ale ona nie była Żydówką. Należała do AK, więc też miała powody, żeby się bać, ale jakoś umiała się obronić. Miała tę pewność siebie, może wrodzoną, może wyszkoloną w podziemiu, nie wiem. Bardzo pięknie mówiła po niemiecku, więc $\mathrm{i}$ to pomagało. Kiedy się poznałyśmy, wciąż miała taką ... no, akowską postawę, formę, można powiedzieć. Akowską w najlepszym wydaniu. Opowiadała, jak w czasie wieczorków przed powstaniem warszawskim deklamowano Norwida A rymem będzie cios miecza. Takie rzeczy. To było bardzo dobre. W filmie dokumentalnym Krzysztofa Bukowskiego Obłoki Marii Janion (tytuł na cześć Obłoków z Trzech zim Miłosza) Maryna wspomina nasze wczesne lata studenckie, tłumaczy, że „to była sytuacja jak za czasów Mickiewicza, kiedy w jednej klasie siedzieli razem nastoletni Mickiewicz i Onufry Pietraszkiewicz, uczestnik wojen napoleońskich”。.

W filmie tym Maria Żmigrodzka mówi także o innym aspekcie doświadczenia wojny i okupacji: o doświadczeniu traumatycznym, które wpłynęło na generacyjne wybory światopoglądowe. Elżbieta Kiślak pisała o związkach młodej badaczki ze środowiskiem lewicowej inteligencji, skupionej wokół „Kuźnicy” i Stefana Żółkiewskiego ${ }^{7}$; ale, jak również zauważa autorka wstępu do wyboru prac Uczonej, „marksizm otwierał drogę refleksji historycznej - uczył widzieć zjawiska na tle całościowych procesów społecznych, dając nie tylko perspektywę syntezy, ale i solidną zaprawę w dialektyce, warsztat analizy" ${ }^{8}$. Od roku 1948

${ }^{4}$ E. Kiślak, Wstęp, [w:] M. Żmigrodzka, Przez wieki idąca powieść. Wybór pism o literaturze XIX i XX wieku, red. M. Kalinowska i E. Kiślak, Warszawa 2002, s. 5.

5 Wypowiedź M. Janion w wywiadzie z K. Szczuką: http://www.krytykapolityczna.pl/artykuly/czytaj-dalej/20130210/ janion-staly-i-mowily (dostęp 05. 01. 2016).

6 Ibidem.

7 Zob. E. Kiślak, op. cit., s. 5.

8 Ibidem, s. 6. 
Maria Żmigrodzka pracowała w Instytucie Badań Literackich Polskiej Akademii Nauk w Warszawie, współtworząc IBL-owską szkołę badań nad romantyzmem, o szczególnym znaczeniu dla powojennych badań nad tą epoką. Od lat 60. prowadziła także zajęcia dydaktyczne na uniwersytetach: Marii Curie-Skłodowskiej w Lublinie (skąd została usunięta w roku 1968, do czego pretekstem stał się przedstawiony na wykładach opis Dejmkowskich Dziadów) oraz Jagiellońskim (od roku 1977 do emerytury).

Pisarstwo naukowe Marii Żmigrodzkiej było w ostatnich latach kilkakrotnie wnikliwie opisywane, zwłaszcza po opublikowaniu w dwa lata po śmierci Uczonej wyboru Jej prac, zatytułowanego Przez wieki idaca powieść. Ukazały się obszerne omówienia i analizy nie tylko tego - przekrojowego - tomu, ale i całej naukowej twórczości Uczonej ${ }^{9}$. W artykułach tych, a także we wstępie do tomu, autorstwa Elżbiety Kiślak, znajdujemy wysokie oceny warsztatu naukowego Marii Żmigrodzkiej oraz miejsca Uczonej we współczesnych badaniach nad wiekiem XIX. Bardzo syntetycznie i wyraziście ujął to Marek Kwapiszewski:

Przez wieki idaca powieść $[. .$.$] doskonale odsłania cechy warsztatu badawczego Marii$ Żmigrodzkiej jako historyka idei i literatury: świetna, gruntowna i wielostronna erudycja, pomysłowość i przenikliwość interpretacyjna, niezwykły talent do kreślonych z intelektualnym rozmachem ujęć syntetyczno-problemowych, połączony z umiejętnością odkrywczego, finezyjnego i wieloaspektowego oglądu konkretu historycznoliterackiego, dostrzeżenia jego złożonej „migotliwości”; nadto - sztukę budowania wywodu rygorystycznie spójnego, maksymalnie pojemnego i zagęszczonego myślowo, w którym zagadnienia szczegółowe włączone są zawsze w refleksję uogólniającą, wywodu wyrażonego polszczyzną piękną i eleganckąa ${ }^{10}$.

Autor wydobywa jeszcze jedną cechę pisarstwa naukowego Marii Żmigrodzkiej: „badaczka maksymalnie esencjalizuje strukturę swoich rozważań. Budując je niemal z samych konkluzji, nieczęsto ujawnia pośrednie etapy drogi, która do nich prowadziła" ${ }^{11}$.

Autorzy wspomnianych opracowań twórczości naukowej Marii Żmigrodzkiej rozpoznali najważniejsze obszary zainteresowań autorki, sytuując je w obrębie nadrzędnego dla Badaczki kręgu problemowego, w którego centrum znajduje się historia. Właśnie historia w różnych problematyzacjach i aspektach - była w centrum zainteresowań badawczych oraz warsztatu Uczonej. Refleksja historyczna i wrażliwość historyczna, tak ważna w pisarstwie naukowym Marii Żmigrodzkiej, jest wyrazem zarówno specyfiki wieku XIX, podstawowego przedmiotu badań Uczonej, jak również konsekwencją doświadczeń generacyjnych i świadomości pokoleniowej. Tu, w tej współzbieżności tkwi chyba jedna z tajemnic aktualności i wartości Jej prac. Sytuują się one w obrębie historii literatury ukierunkowanej ku historii idei, ze szczególnym uwzględnieniem czterech obszarów badań, wyznaczanych przez następujące zagadnienia: historyzm romantyczny, romantyzm a realizm w różnych znaczeniach i aspektach, przekładających się także na zainteresowanie prozą, zagadnienie ironii romantycznej, wreszcie problem mitu i historii, zwłaszcza w romantycznym funkcjonowaniu literatury i idei. Z prac Marii Żmigrodzkiej wyłania się obraz romantyzmu składający się zarówno z romantyzmu „wielkiego”, zwłaszcza istotny jest tu Słowacki, jak i romanty-

\footnotetext{
9 Zob. m.in. E. Kiślak, op. cit.; M. Kwapiszewski, op. cit.; D. Zawadzka [recenzja tomu Przez wieki idacca powieść], „Pamiętnik Literacki” 2006, nr 3; M. Junkiert, „Przez wieki idąca powieść”. Na marginesie studiów Marii Żmigrodzkiej, [w:] Siła komentarza. Romantyzmy literaturoznawców, red. J. Borowczyk, W. Hamerski i P. Śniedziewski, Poznań 2011.

10 M. Kwapiszewski, op. cit., s. 2.

11 Ibidem, s. 3.
} 
zmu „mniejszych” pisarzy, często prozaików, bardzo silnie zakorzenionych w materii społecznego, codziennego życia epoki. Te perspektywy i wątki: historii idei oraz historii form literackich łączą się i przeplatają w pracach Badaczki. Trzeba także zwrócić uwagę na szczególne efekty poznawcze włączania przez Uczoną do refleksji nad romantyzmem kategorii realizmu $^{12}$, co nadaje wizji romantyzmu kształt szczególny, a zarazem buduje w twórczości Profesor Żmigrodzkiej bardzo spójny obraz wieku XIX: znamienne są w tym względzie Jej słowa: „historyzm romantyczny był najżyźniejszą glebą realistycznych tendencji epoki”"13. Bardzo znamienna jest w tym względzie monografia poświęcona Orzeszkowej, pokazująca w wymiarze indywidualnej biografii splatanie się i przenikanie różnych tendencji światopoglądowych i estetycznych, często sztucznie w refleksji literaturoznawczej rozdzielanych i petryfikowanych. Jak już wspomniałam, monografia ta należy do tych prac Uczonej, które nie zestarzały się; do dziś fascynuje, może właśnie dlatego, że jest napisana $\mathrm{z}$ wielkim szacunkiem dla faktów, ze starannością bycia blisko materii historii, a równocześnie - ze zrozumieniem tej materii, z głęboką świadomością procesów historycznych kształtujących caly XIX wiek.

Pisarstwo naukowe Marii Żmigrodzkiej jest bardzo wyważone, pozbawione subiektywności i emocji, łączy precyzyjną analizę faktów z szerokim, panoramicznym spojrzeniem na zjawiska kulturowe. Równocześnie jednak kryje w sobie, jak każde cenne naukowe pisarstwo humanistyczne, ściśle określony system wartości i preferencji, także estetycznych, które budują nie tylko obraz badanego zjawiska, ale i wyrażają własną, autorską wizję świata i człowieka. Wizję ukrytą w kategoriach badawczych, w systemie uruchamianych pojęć, $\mathrm{w}$ wyborach estetycznych, w punktach widzenia, ale także w starannie skrywanych fascynacjach opisywanymi osobami i dziełami. Piszę o tym obszerniej w tekście przedstawiającym wizję romantyzmu w pisarstwie naukowym Marii Żmigrodzkiej ${ }^{14}$. W tym miejscu chcę zwrócić uwagę na preferencje, czy raczej fascynacje Uczonej odnośnie do indywidualności twórczych, którym poświęcała uwagę, na pokrewieństwo wybieranych postaci, pokrewieństwo tyleż rzeczywiste, co wydobywane z ich losów i działań przez spojrzenie życzliwe i wnikliwe. Przyglądając się osobowościom, o których pisała Maria Żmigrodzka, można zaryzykować hipotezę, że fascynuje Autorkę relacja między twórczą jednostką a społeczeństwem, jego konwencjami, strukturą i systemem wartości. Jednostka ta to najczęściej artysta, mierzący się ze społeczeństwem, powiązany z nim na sposób romantyczny, a równocześnie podejmujący czyn artystyczny jako narzędzie budowania swojej wolności, także wewnętrznej wolności, i własnej, jednostkowej tożsamości. Fascynująco opisała Maria Żmigrodzka historycznie uwarunkowaną kondycję kobiecą Elizy Orzeszkowej i jej intelektualny trud budowania swojej nie tylko społecznej pozycji, ale przede wszystkim intelektualnej wolności.

Mistrzostwo historycznoliterackie osiągnęła zatem Uczona nie tylko w panoramicznych, syntetycznych i przekrojowych studiach do dziś zachowujących aktualność, dotyczących najważniejszych problemów i idei romantycznych, ale także w tekstach analitycznych,

12 Przenikliwie opisał to M. Junkiert, op. cit., s. 173 i n.

13 M. Żmigrodzka, Przez wieki..., s. 98.

14 Tekst pt. Marii Żmigrodzkiej wizja romantyzmu ([w:] IBL w PRL. I. Studia $i$ wspomnienia, red. E. Kiślak, Warszawa 2016, ss. 275-297) został przygotowany w ramach projektu NPRH kierowanego przez prof. Elżbietę Kiślak (Nr 11 H 110225 80, Instytut Badań Literackich w życiu naukowym, kulturalnym i społecznym PRL w latach 1948-1989. Postawy inteligencji wobec przemian społecznych i politycznych. Monografia środowiska intelektualnego). 
które łączą perspektywę indywidualną z historią form literackich, a los jednostkowy artysty z dziejami idei i historią społeczeństwa.

W twórczości naukowej Marii Żmigrodzkiej historia stanowi centralne doświadczenie człowieka i XIX, i XX wieku, a równocześnie jest przełamywana czy przezwyciężana przez indywidualny bunt, dystans czy ironię ... I właśnie ironia jest jedną z najważniejszych kategorii w pracach Marii Żmigrodzkiej - rozumiana jako kategoria estetyczna, intelektualna, jak również postawa wobec świata, a nawet stosunek do jakości religijnych. Ironia integruje rozmaite porządki pisarstwa naukowego Marii Żmigrodzkiej, a jej prace o etosie ironii w polskiej literaturze romantycznej znacząco zmieniły obraz romantyzmu polskiego przez wydobycie w nim właśnie postaw ironicznych i włączenie ich w refleksję nad całym paradygmatem romantycznym.

Trudno jednoznacznie odpowiedzieć na sformułowane na początku tego tekstu pytanie o tajemnicę niestarzenia się tekstów Marii Żmigrodzkiej, ich fascynującej nadal aktualności. Może ta tajemnica tkwi w dystansie do opisywanego świata literackiego? Ale przecież jest w tekstach Uczonej głęboko skrywana żarliwość w opisywaniu zmagań jednostki z historią. Może w pokoleniowej wrażliwości historycznej tak współbrzmiącej z historią jako centrum świata XIX wieku? A może w mądrości, która nie pozwala sprowadzić jednostki do narzuconego jej determinizmu historycznego i poszukuje w jej losach śladów duchowej oraz intelektualnej wolności i niezależności? 